\title{
THE EFFECT OF PERINEAL MASSAGE ON PERINEAL STATUS AND DURATION OF LABOR
}

\author{
Priyani Haryanti
}

Lecturer at STIKES Bethesda Yakkum Yogyakarta

\begin{abstract}
Perineal rupture in postpartum mothers causes bleeding, pain, and high dependency on others after the birth. The preliminary study results showed that $68.81 \%$ of postpartum mothers experienced perineal rupture. The aim of this study was to determine the effect of perineal massage on perineal status and length of labor. It was quasi-experimental research with control group post-test only design. The population were all expectant mothers in the Yogyakarta Community Health Center. A sample of 60 respondents were divided into control and intervention groups using a random sampling method. The inclusion criteria were 20-35 years old, singleton pregnancy, spontaneous labor, and gestational age of 34-36 weeks. The study instrument used was an observation sheet. Data were analyzed using descriptive, t-test independent, Mann-Whitney's, and linear regression test. Results. The results showed that perineal massage affects perineal status $(p<0.001)$ and the duration of stage I and stage II of labor $(p<0.001)$. Perineal massage affects perineal status and the duration of labor in the Yogyakarta City Community Health Center.
\end{abstract}

Keywords: Duration of the stage I and stage II of labour, Perineal massage, Perineal status

\section{ABSTRAK}

Ruptur perineum pada ibu post partum dapat menyebabkan perdarahan, nyeri dan ketergantungan pada orang lain. Hasil studi di Puskesmas Tegalrejo dan Jetis menunjukkan jumlah persalinan sebanyak \pm 25 per bulan dan $68,81 \%$ ibu mengalami ruptur perineum. Untuk mengetahui pengaruh pijat perineum terhadap status perineum dan lama persalinan di Puskesmas Kota Yogyakarta. Metode penelitian ini menggunakan quasi eksperimen dengan desain control group post test only design. Populasi penelitian adalah seluruh ibu hamil di Puskesmas Yogyakarta. Sampel pada penelitian ini berjumlah 60 responden yang dibagi menjadi kelompok kontrol dan intervensi secara random. Instrumen penelitian menggunakan lembar observasi. Analisis data secara deskriptif, independent sample t-test, uji Mann-Whitney, dan uji regresi linear. Hasil penelitian menunjukkan terdapat pengaruh pijat perineum terhadap status perineum $p=0,00$, dan lama kala I dan kala II menunjukkan $p=0,00$. Pijat perineum dapat mempengaruhi status perineum dan lama persalinan.

Kata kunci: Lama kala I dan II, Pijat perineum, Status perineum 


\section{BACKGROUND}

The Indonesian government has sought to improve mother and child health by increasing the number of visits of expectant mothers to health care centres (Kemenkes, 2016). Health workers who are competent to conduct examinations are obstetricians, doctors, midwives and nurses (Kemenkes RI, 2015). The visit of K1 (first visitation of expectant mothers to health centres) and K4 (the minimum of four times of expectant mother visitation to health centres) Indonesia's Health Profile on 2014 in Indonesia had not reached 95\% of the target (Kemenkes, 2016). Expectant mother's visit for antenatal care aims to monitor maternal and fetal health, recognise pregnancy complications early on, perform counseling, carry out laboratory tests, and administer iron and tetanus toxoid tablets (which should be done at least four times during pregnancy until delivery) (Kemenkes, 2016).

Childbirth, also known as delivery and labor, is the process of delivering the fetus and placenta which is old enough or can live outside the womb through the birth canal or other passage, with or without assistance (Reeder \& KoniakGriffin, 2012). Most spontaneous labor is always followed by a perineal rupture (Cuningham, Houth, \& Rouse, 2013). Research in the UK showed that perineal rupture due to spontaneous labor was $9.6 \%(125 / 1302)$ in nullipara and $31.2 \%$ (453/1452) in multiparous (Smith, Price, Simonite, \& Burns, 2013a). Other studies in USA showed the percentage of intact perineal at delivery was $9,6 \%(125 / 1302)$ in nullipara, and 31,2\% (453/1452) (Hastings-Tolsma, 2014; Smith et al., 2013a). To prevent extensive rupture, an episiotomy is sometimes performed (Cuningham et al., 2013). An episiotomy is an incision made in the vagina and perineum to widen the soft part of the birth canal and shorten it (Reeder \& KoniakGriffin, 2012). This intervention often draws complaints from postpartum mothers who feel uncomfortable due to pain, psychological disorders and some respondents even said they experience discomfort during intercourse (Dahlen, Mid, Priddis, Mid, \& Thornton, 2015;
Priddis, Schmied, Kettle, Sneddon, \& Dahlen, 2014).

Previous study results have shown that patients who performed perineal massage using a digital tool in the third trimester rarely have to go through an episiotomy (Beckmann \& Stock, 2013). Perineal massage is a massage performed on the perineum which is carried out 5-7 times a week during the last five to six months into the pregnancy (Bulchandani, Watts, Sucharitha, Yates, \& Ismail, 2015). The research conducted by Geranmayeh et al (2012) shows that perineal massage performed during stage II of labor using Vaseline is statistically proven to ensure a more intact perineum and thus lower episiotomy degree. Nursing interventions during labor can have a direct impact on the need for an episiotomy (Cuningham et al., 2013). Proposed steps to increase perineal stretching and reduce perineal trauma include applying warm compresses, gentle perineal massage, pelvic floor training and by using warm oil during the stage II of labor (Hastings-Tolsma, 2014; Leon-Larios, Corrales-Gutierrez, CasadoMejía, \& Suarez-Serrano, 2017; Wang, Jayasekara, \& Warland, 2015). The research done by Aasheim, Abv, Lm, \& Lukasse (2017) compared the effectiveness of perineal massage, warm compresses, and perineal management proved that in the perineal massage group there was a decrease of three and four degrees of perineal rupture.

Some literature has shown the benefits of perineal massage. With said benefits, perineal massage can be applied to the Yogyakarta community, because it is proven to be safe. From the preliminary studies at the Tegalrejo and Jetis Community Health Centers, the average number of deliveries in 2017 was 25 per month and $68.81 \%$ of those women experienced perineal rupture. In the interview with health workers who assisted the labor, they said rupture occurred when the perineal was rigid and thick, which made the stage I last longer. Postpartum mothers stated that perineal rupture caused bleeding and pain, which made 
them uncomfortable while taking care of their babies.

The research aimed to identify the effect of perineal massage on perineal status and the duration of labor in Yogyakarta's Community Health Center.

\section{METHODS}

This research used a quasiexperimental method with a nonequivalent control group post test only. The population were all pregnant women who received antenatal care at the Community Health Center in Yogyakarta. There were 60 respondents which were randomly divided into control groups and interventions group. Inclusion criteria were -women between 20-35 years old, with a singleton pregnancy, spontaneous labor, were willing to be a respondent, with no pregnancy complications and gestational age of 34-36 weeks. The assistants were provided with a perineal massage training and booklet and then they would do a home visit to give perineal massage for 15 minutes a day (Geranmayeh et al., 2012). Expectant mothers in the intervention group were given a perineal massage training and booklet. The booklet was about perineal massage with a compliance check-list which must be filled out by the assistants. The pregnant women were expected to do the massage by themselves at home for 15 minutes a day, 6 times a week. Later, assistants would do a home visit to remind and guide the expectant mothers in doing the massage. To do the perineal massage, first you must wash your hands and apply Virgin Coconut Oil (VCO). Research shows that VCO is beneficial as an anti-inflamatory and protects the skin (Varma et al., 2019). If the expectant mothers do the massage by themselves, they should use the thumb, but if the assistants are the one who do it, they should use the pointing finger. Insert thumb or pointing finger in the vagina until the second finger bone segment. After that, the expectant mother should do kegel (pelvic floor contraction) so that thumb or pointing finger can feel the tensed muscles. Relax the pelvic floor and move the thumb or pointing finger on the vagina by making a $U$ movement while pushing outside and inside towards the rectal area. Patients are guided to focus on the relaxation of muscles when they feel any pressure and stretch.

This research used percent agreement with ten assistants with Diploma and Bachelor Degrees of Midwifery. The assistants observed the perineal wound, and the duration of stage I and stage II. The observation resulted in $80 \%$ agreement. Perineal status was measured based on the rupture using the theory by Cuningham et al (2013), which divides the degree of perineal rupture into four stages. Laceration is categorized as stage I if it reached the fourchette, perineal skin and vaginal mucous membrane but not the fascia and the muscles below. It is included in the second degree of laceration if it reached the fascia and perineal muscles, on the side of the skin and mucous membrane, but not sphincter ani. The rupture is usually expanded upward on one or both sides of the vagina causing a triangular shaped wound. The laceration is categorized as third degree if it expanded through the skin, mucous membrane, perineal corpus and sphincter ani. While the fourth degree laceration is if it expanded through rectal mucous that meant the rectal lumen was exposed. The rupture in the urethral area which causes heavy bleeding most likely happens in this type of laceration. The duration of labor was measured using an observation checklist and the clock in the delivery room. Stage $I$ is the duration of $1-10 \mathrm{~cm}$ opening until complete opening, which would be observed after the mother enters the delivery room. Stage II is the duration from complete opening until delivery. The measurement of perineal status and duration of delivery was done after the delivery was completed/stage II (Reeder \& Koniak-Griffin, 2012).

The data were analysed using independent sample t-test and the MannWhitney test. Then, the data were analysed using simple linear regression. This study passed the ethical clearance at Ethics Committee of Medical Faculty of Universitas Kristen Duta Wacana (Duta Wacana Christian University) Yogyakarta 
Jurnal Keperawatan Soedirman 14 (2) 2019 : 145 - 155

with registration number:459/C.16/FK/ 2017.

\section{RESULTS}

1. Univariate Analysis

Characteristics of respondents

Table 1. Characteristics of Frequency Distribution of Delivering Mothers and Babies in Yogyakarta's Community Health Center

\begin{tabular}{|c|c|c|c|}
\hline \multirow{2}{*}{ Characteristics of respondent } & \multicolumn{2}{|c|}{ Group } & \multirow{2}{*}{$P$ value } \\
\hline & Intervention $(\mathrm{n}=30)$ & Control $(n=30)$ & \\
\hline \multicolumn{4}{|l|}{ Age } \\
\hline 20-35 years old & 17 (28.33\%) & $23(38.33 \%)$ & 0.85 \\
\hline$<20$ and $>35$ years old & $13(21.67 \%)$ & $7(11.66 \%)$ & \\
\hline \multicolumn{4}{|l|}{ Level of education } \\
\hline Elementary stage & $8(13.33 \%)$ & $7(11.66 \%)$ & \\
\hline Secondary stage & $19(31.66 \%)$ & $22(36.66 \%)$ & 0.81 \\
\hline Higher stage & $3(5 \%)$ & $1(1.6 \%)$ & \\
\hline \multicolumn{4}{|l|}{ Parity } \\
\hline Primipara & $14(23.33 \%)$ & $11(18.33 \%)$ & 0.3 \\
\hline Multipara & $16(26.66 \%)$ & $19(31.66 \%)$ & \\
\hline \multicolumn{4}{|l|}{ Baby's Weight } \\
\hline $2500-4000 \mathrm{gr}$ & $28(46.67 \%)$ & $28(46.67 \%)$ & 0.69 \\
\hline$<2500 \mathrm{gr}$ and $>4000 \mathrm{gr}$ & $2(3.33 \%)$ & $2(3.33 \%)$ & \\
\hline \multicolumn{4}{|l|}{ Baby's Sex } \\
\hline Male & $12(20 \%)$ & $19(31.66 \%)$ & 0.06 \\
\hline Female & $18(30 \%)$ & $11(18.33 \%)$ & \\
\hline
\end{tabular}

Table 1 shows the majority of mothers in the control group were aged between 20-35 years old (23 respondents $(38.33 \%)), 22$ respondents had completed secondary education level, and 19 $(31.66 \%)$ respondents were multiparous. $P$ value of $>0.05$ shows no difference between the intervention and control groups. These results showed homogeneous maternal characteristics.
Table 1. shows that most newborn weight ranged between $2500 \mathrm{gr}$ $4000 \mathrm{gr}$ (28 respondents (46.67\%)). In the intervention group, the baby's sex was mostly female (18 respondents $(30 \%)$ ). $P$ value $>0.05$ shows that there is no difference between intervention and control groups. This result shows that the respondent's characteristics are homogenous.

2. The Effect of Perineal Massage on the Perineal Status and the Duration of Delivery

a. The effect of perineal massage on perineal status

Table 2. The Effect of Perineal Massage on Perineal Status of Delivering Mothers in the Yogyakarta Community Health Center

\begin{tabular}{lcccc}
\hline & Perineal status & Intervention & Control & $\boldsymbol{p}$ value \\
\hline Intact & 7 & 0 & 0.00 \\
\hline Degree 1 & 15 & 1 & \\
\hline Degree 2 & 8 & 20 & \\
\hline Degree 3 & 0 & 9 & \\
\hline
\end{tabular}

Table 2 shows $p$ value of $0.00<0.05$ using Mann-Whitney analysis, which means that perineal massage has an impact on perineal status. 
Jurnal Keperawatan Soedirman 14 (2) 2019 : 145 - 155

b. The effect of perineal massage on the duration of stage I and stage II of delivery

Table 3. The Effect of Perineal Massage on the Duration of Stage I of Delivering Mother in Yogyakarta's Community Health Center

\begin{tabular}{lccccccccc}
\hline \multicolumn{1}{c}{ Variable } & \multicolumn{3}{c}{$\begin{array}{l}\text { With perineal } \\
\text { massage }\end{array}$} & \multicolumn{3}{c}{$\begin{array}{c}\text { Without perineal } \\
\text { massage }\end{array}$} & $\begin{array}{c}\text { Average } \\
\text { difference }\end{array}$ & $\boldsymbol{P}$ & Cl 95\% \\
\cline { 2 - 9 } & $\mathbf{n}$ & Average & \pm SD & $\mathbf{N}$ & Average & \pm SD & & & \\
\hline $\begin{array}{l}\text { Duration of } \\
\text { stage I }\end{array}$ & 30 & 470 & $123-$ & 30 & 617 & 157 & -147 & 0.00 & $-219.9--220$ \\
\hline $\begin{array}{l}\text { Duration of } \\
\text { stage II }\end{array}$ & 30 & 53.3 & 25.9 & 30 & 70.7 & 31 & -17 & 0.02 & $-32.12--32.14$ \\
\hline
\end{tabular}

Table 3 shows the effect of perineal massage on the duration stage I and stage II of labor in Yogyakarta's Community Health Center. Analyzed using the independent sample t test, shows $p$ value of $0.00<0.05$, which means that perineal massage has an impact on the duration of the stage I and stage II labour.

3. The Effect of Perineal Massage on Perineal Status and Duration of Delivery by Controlling External Variables

a. The effect of perineal massage on perineal status by controlling outside variables

Table 4. Effect of Perineal Massage on Perineal Status by Controlling Outside Variables

\begin{tabular}{|c|c|c|c|c|c|c|}
\hline Variable & $\begin{array}{c}\text { Model.1 } \\
\text { Coefficient } \\
\text { Cl } \\
\text { P value }\end{array}$ & $\begin{array}{c}\text { Model.2 } \\
\text { Coefficient } \\
\text { Cl } \\
\text { P value }\end{array}$ & $\begin{array}{c}\text { Model. } 3 \\
\text { Coefficient } \\
\text { Cl } \\
\mathrm{P} \text { value }\end{array}$ & $\begin{array}{c}\text { Model.4 } \\
\text { Coefficient } \\
\text { Cl } \\
\text { P value }\end{array}$ & $\begin{array}{c}\text { Model.5 } \\
\text { Coefficient } \\
\text { Cl } \\
\text { P value }\end{array}$ & $\begin{array}{c}\text { Model. } 6 \\
\text { Coefficient } \\
\mathrm{Cl} \\
\mathrm{P} \text { value }\end{array}$ \\
\hline $\begin{array}{l}\text { Perineal } \\
\text { massage }\end{array}$ & $\begin{array}{c}1.2 \\
0.9-1.5 \\
0.00\end{array}$ & $\begin{array}{c}1.2 \\
0.95-1.6 \\
0.00\end{array}$ & $\begin{array}{c}1.2 \\
0.9-1.6 \\
0.00\end{array}$ & $\begin{array}{c}1.2 \\
1-1.5 \\
0.00\end{array}$ & $\begin{array}{c}1.2 \\
0.9-1.5 \\
0.00\end{array}$ & $\begin{array}{c}1.3 \\
1.0-1.6 \\
0.00\end{array}$ \\
\hline $\begin{array}{l}\text { Age } \\
20-35 \text { years } \\
<20 \text { and }>35 \\
\text { years }\end{array}$ & & $\begin{array}{c}0.2 \\
-0.14-0.56 \\
0.23\end{array}$ & & & & $\begin{array}{c}0.16 \\
-0.15-0.48 \\
0.3\end{array}$ \\
\hline $\begin{array}{l}\text { Level of } \\
\text { education }\end{array}$ & & & $\begin{array}{c}-0.14 \\
-0.32-0.29 \\
0.93\end{array}$ & & & $\begin{array}{c}-0.03 \\
-0.32-0.25 \\
0.81\end{array}$ \\
\hline $\begin{array}{l}\text { Parity } \\
\text { Primipara } \\
\text { Multipara } \\
\end{array}$ & & & & $\begin{array}{c}-0.59 \\
-0.89--0.30 \\
0.00 \\
\end{array}$ & & $\begin{array}{c}-0.56 \\
-0.86--0.25 \\
0.01 \\
\end{array}$ \\
\hline $\begin{array}{l}\text { Baby's weight } \\
2500-4000 \mathrm{gr} \\
<2500 \mathrm{gr} \text { and } \\
>4000 \mathrm{gr}\end{array}$ & & & & & $\begin{array}{c}0.64 \\
0.0-1.2 \\
0.047\end{array}$ & $\begin{array}{c}0.42 \\
-0.19-0.99 \\
0.18\end{array}$ \\
\hline $\begin{array}{l}\text { Adjustable } \mathrm{R}^{2} \\
\text { Constants } \\
\mathrm{N}\end{array}$ & $\begin{array}{l}0.49 \\
0.8 \\
60\end{array}$ & $\begin{array}{l}0.49 \\
0.45 \\
60\end{array}$ & $\begin{array}{c}0.48 \\
0.82 \\
60\end{array}$ & $\begin{array}{c}0.59 \\
1.66 \\
60\end{array}$ & $\begin{array}{c}0.51 \\
0.11 \\
60\end{array}$ & $\begin{array}{c}0.60 \\
0.96 \\
60\end{array}$ \\
\hline
\end{tabular}

Based on table 4, the analysis shows that perineal massage has a regression coefficient of 1.3 with $p$ value of
$0.00(<0.05)$. This model has an adjusted value of $R^{2}$ of 0.60 . 
Jurnal Keperawatan Soedirman 14 (2) 2019 : 145 - 155

b. The effect of perineal massage on the duration of the stage I by controlling the external variables

Table 5. Linear Regression Analysis: The Effect of Perineal Massage on the Duration of the Stage I Delivery by Controlling the External Variables

\begin{tabular}{|c|c|c|c|c|c|c|}
\hline Variable & $\begin{array}{c}\text { Model.1 } \\
\text { Coefficient } \\
\text { Cl } \\
\mathrm{P} \text { value } \\
\end{array}$ & $\begin{array}{c}\text { Model.2 } \\
\text { Coefficient } \\
\mathrm{Cl} \\
\mathrm{P} \text { value } \\
\end{array}$ & $\begin{array}{c}\text { Model.3 } \\
\text { Coefficient } \\
\text { Cl } \\
\mathrm{P} \text { value } \\
\end{array}$ & $\begin{array}{c}\text { Model.4 } \\
\text { Coefficient } \\
\text { Cl } \\
\mathrm{P} \text { value } \\
\end{array}$ & $\begin{array}{c}\text { Model.5 } \\
\text { Coefficient } \\
\mathrm{Cl} \\
\mathrm{P} \text { value } \\
\end{array}$ & $\begin{array}{c}\text { Model.6 } \\
\text { Coefficient } \\
\text { Cl } \\
\text { P value }\end{array}$ \\
\hline $\begin{array}{l}\text { Perineal } \\
\text { massage }\end{array}$ & $\begin{array}{c}147 \\
74-219 \\
0.00\end{array}$ & $\begin{array}{c}136 \\
62-211 \\
0.00\end{array}$ & $\begin{array}{c}149 \\
77-220 \\
0.00\end{array}$ & $\begin{array}{c}164 \\
105-223 \\
0.00\end{array}$ & $\begin{array}{c}147 \\
73-220 \\
0.00\end{array}$ & $\begin{array}{c}154 \\
96-214 \\
0.00\end{array}$ \\
\hline $\begin{array}{l}\text { Age } \\
20-35 \text { years } \\
<20 \text { and }>35 \\
\text { years }\end{array}$ & & $\begin{array}{c}-50 \\
-129-27 \\
0.2\end{array}$ & & & & $\begin{array}{c}-48 \\
-113-16 \\
0.14\end{array}$ \\
\hline $\begin{array}{l}\text { Level of } \\
\text { education }\end{array}$ & & & $\begin{array}{c}61 \\
-5.9-128 \\
0.073\end{array}$ & & & $\begin{array}{c}26,69 \\
-31.3-84.7 \\
0.36\end{array}$ \\
\hline $\begin{array}{l}\text { Parity } \\
\text { Primipara } \\
\text { Multipara }\end{array}$ & & & & $\begin{array}{c}-171 \\
-231--111 \\
0.00\end{array}$ & & $\begin{array}{c}-167 \\
-229--106 \\
0.00\end{array}$ \\
\hline $\begin{array}{l}\text { Baby's weight } \\
\text { 2500-4000gr } \\
<2500 \mathrm{gr} \text { and } \\
>4000 \mathrm{gr}\end{array}$ & & & & & $\begin{array}{c}44 \\
-102-191 \\
0.55\end{array}$ & $\begin{array}{c}2.33 \\
-118.6-123 \\
0.96\end{array}$ \\
\hline $\begin{array}{l}\text { Adjustable R2 } \\
\text { Constants } \\
\mathrm{N}\end{array}$ & $\begin{array}{c}0.20 \\
323 \\
60\end{array}$ & $\begin{array}{c}0.21 \\
406 \\
60\end{array}$ & $\begin{array}{l}0.24 \\
208 \\
60\end{array}$ & $\begin{array}{c}0.49 \\
568 \\
60\end{array}$ & $\begin{array}{l}0.19 \\
275 \\
60\end{array}$ & $\begin{array}{c}0.49 \\
590 \\
60\end{array}$ \\
\hline
\end{tabular}

Based on the 5th table of the model, the results of the analysis show that perineal massage has a regression coefficient of 159 with a $p$ value of 0.00 $(<0.05)$. This model has an adjusted value of $R^{2}$ of 0.49 .

c. The effect of Perineal massage on the duration of the stage II by controlling the external variables

Table 6. The Effect of Perineal Massage on the Duration of the Stage II by Controlling the External Variables

\begin{tabular}{|c|c|c|c|c|c|c|}
\hline Variable & $\begin{array}{c}\text { Model.1 } \\
\text { Coefficient } \\
\text { Cl } \\
\mathrm{P} \text { value }\end{array}$ & $\begin{array}{c}\text { Model.2 } \\
\text { Coefficient } \\
\text { Cl } \\
P \text { value }\end{array}$ & $\begin{array}{c}\text { Model.3 } \\
\text { Coefficient } \\
\text { Cl } \\
\text { P value }\end{array}$ & $\begin{array}{c}\text { Model.4 } \\
\text { Coefficient } \\
\text { Cl } \\
\text { P value }\end{array}$ & $\begin{array}{c}\text { Model.5 } \\
\text { Coefficient } \\
\text { Cl } \\
\mathrm{P} \text { value }\end{array}$ & $\begin{array}{c}\text { Model. } 6 \\
\text { Coefficient } \\
\text { Cl } \\
\text { P value }\end{array}$ \\
\hline $\begin{array}{l}\text { Perineal } \\
\text { massage }\end{array}$ & $\begin{array}{c}17.33 \\
2.54-32.1 \\
0.00 \\
\end{array}$ & $\begin{array}{c}18.93 \\
3.79-34.07 \\
0.01 \\
\end{array}$ & $\begin{array}{c}17.5 \\
2.6-32.4 \\
0.02 \\
\end{array}$ & $\begin{array}{c}20.2 \\
7.3-33.1 \\
0.03 \\
\end{array}$ & $\begin{array}{c}17.33 \\
2.41-32.3 \\
0.02 \\
\end{array}$ & $\begin{array}{c}22 \\
8.67-35.36 \\
0.002 \\
\end{array}$ \\
\hline $\begin{array}{l}\text { Age } \\
20-35 \text { years } \\
<20 \text { and }>35 \\
\text { years }\end{array}$ & & $\begin{array}{c}8 \\
-8-24 \\
0.32\end{array}$ & & & & $\begin{array}{c}8.2 \\
-6.3-22 \\
0.26\end{array}$ \\
\hline $\begin{array}{l}\text { Level of } \\
\text { education }\end{array}$ & & & $\begin{array}{c}5 \\
-8.92-19 \\
0.47\end{array}$ & & & $\begin{array}{c}1.2 \\
-11.7-14 \\
0.85\end{array}$ \\
\hline $\begin{array}{l}\text { Parity } \\
\text { Primipara } \\
\text { Multipara }\end{array}$ & & & & $\begin{array}{c}-29.17 \\
7.3-33.2 \\
0.00\end{array}$ & & $\begin{array}{c}-30.04 \\
-43.7--16.3 \\
0.00\end{array}$ \\
\hline
\end{tabular}


Jurnal Keperawatan Soedirman 14 (2) 2019 : 145 - 155

\begin{tabular}{|c|c|c|c|c|c|c|}
\hline Variable & $\begin{array}{c}\text { Model.1 } \\
\text { Coefficient } \\
\text { Cl } \\
\mathrm{P} \text { value }\end{array}$ & $\begin{array}{c}\text { Model.2 } \\
\text { Coefficient } \\
\text { Cl } \\
\text { P value }\end{array}$ & $\begin{array}{c}\text { Model.3 } \\
\text { Coefficient } \\
\text { Cl } \\
\text { P value }\end{array}$ & $\begin{array}{c}\text { Model.4 } \\
\text { Coefficient } \\
\text { Cl } \\
\mathrm{P} \text { value }\end{array}$ & $\begin{array}{c}\text { Model.5 } \\
\text { Coefficient } \\
\mathrm{Cl} \\
\mathrm{P} \text { value }\end{array}$ & $\begin{array}{c}\text { Model.6 } \\
\text { Coefficient } \\
\mathrm{Cl} \\
\mathrm{P} \text { value }\end{array}$ \\
\hline $\begin{array}{l}\text { Baby weight } \\
2500-4000 \mathrm{gr} \\
<2500 \mathrm{gr} \\
\text { and }>4000 \mathrm{gr}\end{array}$ & & & & & $\begin{array}{c}-2.1 \\
-32-27 \\
0.89\end{array}$ & $\begin{array}{c}-13.9 \\
-40.9-13 \\
0.3\end{array}$ \\
\hline $\begin{array}{l}\text { Adjustable } \mathrm{R}^{2} \\
\text { Constants } \\
\mathrm{N}\end{array}$ & $\begin{array}{c}0.071 \\
36 \\
60\end{array}$ & $\begin{array}{c}0.071 \\
406 \\
60\end{array}$ & $\begin{array}{c}0.06 \\
26.57 \\
60\end{array}$ & $\begin{array}{c}0.29 \\
77.80 \\
60\end{array}$ & $\begin{array}{c}0.55 \\
32.28 \\
60\end{array}$ & $\begin{array}{c}0.29 \\
78.3 \\
60\end{array}$ \\
\hline
\end{tabular}

Based on the 6th table, the analysis shows that perineal massage has a regression coefficient of 22 with a $p$ value of $0.002(<0.05)$. This model has an adjusted value of $R 2$ of 0.29 .

\section{DISCUSSION}

1. The Effect of Perineal Massage on the Perineal Status

The results of the analysis in table 2 showed the $p=0.00$ which means that perineal massage has an impact on the perineal status. This means that $\mathrm{H}$ alpha is accepted and $\mathrm{H}$ zero is rejected, thus meaning that perineal massage does affect perineal status. The anterior, posterior, and lateral borders of the perineum are namely the anterior symphysis pubis, the ischiopubic ramus, and the anterolateral ischiadicum tuberosity, the posterolateral sacrotuberale ligament, and the posterior coccyx (Cuningham et al., 2013). Perineal massage, which is taught once and carried out routinely by pregnant women during the third trimester by moving the finger inside the vagina forming the $U$ letter for 15 minutes, aims to flex the perineal muscle (Bulchandani et al., 2015). The gradual massage aims to flex the superficial perineal transverse muscles and ischioanal fossa in the posterior trigeminal (Cuningham et al., 2013). Ischioanal fossa serves to provide space for rectal distension and stretch during childbirth (Cuningham et al., 2013). The anterior and posterior trigeminal are connected by imaginary lines that connect the two ischiatic tuberosity (Cuningham et al., 2013).

This is in line with the theory which stated that perineal massage affects perineal status (Beckmann \& Stock, 2013). It is supported by meta-analysis research which says that perineal massage does not pose a harmful risk to the mother and fetus, as evidenced by many women who voluntarily receive perineal massage (Bulchandani et al., 2015; Ismail \& Emery, 2013).

\section{The Effect of Perineal Massage on} the Duration of the Stage I of Delivery

The results of the analysis in Table 3 shows $p=0.00$, which means that perineal massage has an impact on the duration of the stage I of the delivery. The stage $I$ is the opening of $1-10 \mathrm{~cm}$ of the birth canal, which is divided into latent, active, and transitional phases (Reeder \& Koniak-Griffin, 2012). Each phase has a different duration for the progress of labor (Cuningham et al., 2013). Duration of the latent phase in nulliparous is 8.6 hours while multipara is 5.3 hours (Cuningham et al., 2013). The duration of the active phase in nulliparous is 4.6 hours while multipara is 2.4 hours (Cuningham et al., 2013). The duration of the transitional phase is during the opening of $8-10 \mathrm{~cm}$ (Reeder \& Koniak-Griffin, 2012). The mean difference in the intervention and control groups was 147, meaning that perineal massage accelerates stage I by 147 minutes.

\section{The Effect of Perineal Massage to the} Duration of Stage II of Delivery

Table 3 shows the results of $p=0.00$, which means that perineal massage has an impact on the duration of the stage II of the delivery. The mean of intervention group was 53.3 minutes and 
the control group was 70.7 minutes. This was supported by a theory which stated that the duration of stage II in nulliparous is 1 hour and in multiparas is $1 / 4-1 / 2$ hours (Reeder \& Koniak-Griffin, 2012). Average difference is -17 which means perineal massage accelerates stage II by 17 minutes. The stage II is called pelvic stage from the opening until the labor (Reeder \& Koniak-Griffin, 2012). The duration of the stage II of labor - Cuningham et al (2013). says the median of stage II is 50 minutes for nulliparous and 20 minutes for multiparous.

\section{The Effect of Perineal Massage on Perineal Status and Duration of Delivery by Controlling External Variables}

Table 4 shows the linear regression analysis of the impact of perineal massage on the perineal status by controlling external variables. The analysis shows that perineal massage has a coefficient regression of 1.3 with $p=0.00$ which means there is a correlation between perineal massage and perineal status by controlling the age, the level of education, parity of the mother and the weight of the baby. This means that perineal massage which was taught once and carried out by the mother once a day for 15 minutes could prevent them from experiencing a rupture, or in other words, having a more intact perineal status by 1.3 points. This model has adjusted R2 of 0.60 which means perineal massage treatment for pregnant women could affect perineal status by $60 \%$ or $40 \%$ depending on other factors which have not been examined in this study.

The results of this study are different from the results of Zare, Pasha, \& Faramarzi (2014) study which stated that perineal massage does not provide any benefit to the perineal status. This study follows the same weaknesses of previous research. In this study, the perineal massage intervention is carried out during the period of the third trimester of the pregnancy. Respondents regularly perform the massage slowly to relax and flex the superficial transverse perineal muscle and ischioanal fossa in the posterior trigeminus while in the previous study mentioned it was only carried out during labor. Multivariate analysis shows that perineal massage only affects the perineal status by $60 \%$ and this is supported by a previous study, which stated that perineal rupture is caused by the duration of stage II, the weight of the baby, difficulties in the stage II, delivery with occipito posterior, and delivery by a diabetic mother (Hauck, Lewis, Nathan, White, \& Doherty, 2015; Priddis et al., 2014; Smith, Price, Simonite, \& Burns, 2013b). This research is supported by previous research which stated that perineal massage during the third trimester of pregnancy and during the stage II reduces the risk of episiotomy and reduces the degree of perineal injury (Aquino et al., 2018; Demirel \& Golbasi, 2015).

Table 5 shows the linear regression analysis of the effect of perineal massage on the duration of the stage I of delivery by controlling external variables (age, education level, parity of the mother, and the weight of baby). The results of the analysis shows perineal massage has a regression coefficient of 159 with $p$ value as much as 0.00 , which means there is a correlation between perineal massage and the duration of the stage I. It means that perineal massage which was taught once and performed at home once a day by expectant mothers could accelerate the stage I by 159 minutes ( 2 hours 39 minutes). This model has an adjusted $R^{2}$ value of 0.49 which means perineal massage during pregnancy can affect the stage I by $49 \%$ and the other $61 \%$ are influenced by other factors, which have not been examined in this study. Stage I is the $1-10 \mathrm{~cm}$ opening of the birth canal. The duration of one latent phase is 8.5 hours for nullipara and 5.3 hours for multipara. The duration of one active phase to transition phase is 4.5 hours for nullipara and 2.4 hours for multipara (Reeder \& Koniak-Griffin, 2012). Delivery often causes injury to the birth canal. Injuries in the birth canal occur on: pelvic floor/perineal, vulva and vagina, uterine cervix, uterus. While for spontaneous labor, perineal rupture is caused by: stiff perineal, fetal head's passing too quickly through the pelvic 
floor, the baby's size, perineal width, parity (Reeder \& Koniak-Griffin, 2012). When stimulation is done from the third trimester it will flex and relax the maternal perineal so that delivery becomes more comfortable. Mothers who feel relaxed during stage II will make the descent of the fetal head easier and accelerate the delivery.

Table 6 shows the linear regression analysis of the effect of perineal massage toward the duration of stage II by controlling the external variables (age, educational level, parity of the mother, and the weight of the baby). The results of the analysis showed that perineal massage had a regression coefficient of 22 with $p=0.002$, which means that perineal massage had an impact on stage II of the delivery. This means that perineal massage done by pregnant mothers accelerates stage II by 22 minutes. This model has an adjusted R2 value of 0.29 which means that perineal massage during pregnancy can affect the duration of the stage II by $29 \%$ and the other $71 \%$ is influenced by other variables, which have not been examined in this study.

In the stage II, the labor begins when the cervix is fully dilated until the baby is born (Cuningham et al., 2013). The duration of the stage II is around 4.5 hours for nullipara and 2.4 hours for multiparous (Reeder \& Koniak-Griffin, 2012). Perineal massage accelerates stage II by 22 minutes. This is supported by the research, which stated that perineal massage accelerates the duration of the stage II with an odds ratio of 1.45 (Hastings-Tolsma, 2014; Smith et al., 2013a). Other studies have shown that perineal massage does not cause trauma, perineal pain and does not draw complaints from the mother after childbirth (Hastings-Tolsma, 2014; Karaçam, Ekmen, \& Çalişir, 2012). Prenatal perineal massage allows the expectant mother to experience the same sensation which she would feel while the baby is being delivered and that gives her the opportunity to practice relaxing the perineal when it comes to labor, as evidenced by $87 \%$ of the 2480 respondents recommending perineal massage to others (Beckmann \& Stock, 2013). This adaptation makes the perineal become flexible so that labor becomes easier (Cuningham et al., 2013).

\section{CONCLUSION}

Perineal massage has an impact on perineal status and the duration of the stage I and stage II of delivery. Perineal massage prevents perineal rupture and accelerates the duration of stage $I$ and stage II of delivery.

\section{REFERENCES}

Aasheim, V., Abv, N., Lm, R., \& Lukasse, M. (2017). Perineal techniques during the second stage of labour for reducing perineal trauma (Review). 1(6),1-115.https://doi.org/10.1002/1 4651858.CD006672.pub3.www.coch ranelibrary.com

Aquino, C. I., Guida, M., Saccone, G., Cruz, Y., Vitagliano, A., Zullo, F., \& Berghella, V. (2018). Perineal massage during labor: a systematic review and meta-analysis of randomized controlled trials. The Journal of Maternal-Fetal \& Neonatal Medicine, 7058, 1-13. https://doi.org/10.1080/14767058.20 18.1512574

Beckmann, M. M., \& Stock, O. M. (2013). Antenatal massage for reducing perineal trauma (Cochrane Review). The Cochrane Library, 1(4), 1. https://doi.org/10.1002/14651858.CD 005123.pub3.www.cochranelibrary.c om

Bulchandani, S., Watts, E., Sucharitha, A., Yates, D., \& Ismail, K. M. (2015). Manual perineal support at the time of childbirth: A systematic review and meta-analysis. BJOG: $A n$ International Journal of Obstetrics and Gynaecology, 122, pp. 11571165. https://doi.org/10.1111/14710528.13431

Cuningham, L., Houth, B., \& Rouse, S. (2013). Obstetri Williams. Jakarta.: EGC. 
Dahlen, H. G., Mid, G. C., Priddis, H., Mid, G. D., \& Thornton, C. (2015). Severe perineal trauma is rising, but let us not overreact. Midwifery, 31(1), 1-8. https://doi.org/10.1016/j.midw.2014.0 9.004

Demirel, G., \& Golbasi, Z. (2015). Effect of perineal massage on the rate of episiotomy and perineal tearing. International Journal of Gynecology and Obstetrics, 131(2), 183-186. https://doi.org/10.1016/j.ijgo.2015.04 .048

Geranmayeh, M., Habibabadi, Z. R., Fallahkish, B., Farahani, M. A., Khakbazan, Z., \& Mehran, A. (2012). Reducing perineal trauma through perineal massage with vaseline in second stage of labor. Archives of Gynecology and Obstetrics, 285(1), 77-81. https://doi.org/10.1007/s004 04-011-1919-5

Hastings-Tolsma, M. (2014). Antenatal perineal massage decreases risk of perineal trauma during birth. Evidence Based Nursing, 17(3), 7777. https://doi.org/10.1136/eb-2013101451

Hauck, Y. L., Lewis, L., Nathan, E. A., White, C., \& Doherty, D. A. (2015). Risk factors for severe perineal trauma during vaginal childbirth: A Western Australian retrospective cohort study. Women and Birth, 28(1), 16-20. https://doi.org/10.1016 /j.wombi.2014.10.007

Ismail, S. I. M. F., \& Emery, S. J. (2013). Patient awareness and aceptability of antenatal perineal massage. Journal of Obstetrics and Gynaecology, 33(8), 839-843. https://doi.org/10.3109/01443615.20 13.828027

Karaçam, Z., Ekmen, H., \& Çalişir, $H$. (2012). The Use of Perineal Massage in the Second Stage of Labor and Follow-Up of Postpartum Perineal Outcomes. Health Care for Women International, 33(8), 697- 718.https://doi.org/10.1080/0739933

2.2012 .655385

Kemenkes. (2016). Profil Kesehatan Indonesia Tahun 2015. Jakarta: Kementrian Kesehatan RI 2016.

Kemenkes RI. (2015). Permenkes RI Nomor 97 Tahun 2014 Tentang Pelayanan Kesehatan Masa Sebelum Hamil, Masa Hamil, Persalinan, dan Masa Sesudah Melahirkan, Penyelenggaraan Pelayanan Kontrasepsi, Serta Pelayanan Kesehatan Seksual. Pelayanan Kesehatan Masa.

Leon-Larios, F., Corrales-Gutierrez, I., Casado-Mejía, R., \& SuarezSerrano, C. (2017). Influence of a pelvic floor training programme to prevent perineal trauma: A quasirandomised controlled trial. Midwifery, $50 \quad$ (1), 72-77. https://doi.org/10.1016/j.midw.2017.0 3.015

Priddis, H. S., Schmied, V., Kettle, C., Sneddon, A., \& Dahlen, H. G. (2014). " A patchwork of services" caring for women who sustain severe perineal trauma in New South Wales - from the perspective of women and midwives. $B M C$ Pregnancy and Childbirth, 14(1), 114. https://doi.org/10.1186/1471-239 3-14-236

Reeder, M., \& Koniak-Griffin. (2012). Keperawatan Maternitas: Kesehatan Wanita, Bayi, dan Keluarga (Volume 1) (18th ed.). Jakarta: EGC.

Smith, L. A., Price, N., Simonite, V., \& Burns, E. E. (2013a). Incidence of and risk factors for perineal trauma: A prospective observational study. BMC Pregnancy and Childbirth, 13, 1-9. https://doi.org/10.1186/14712393-13-59

Smith, L. A., Price, N., Simonite, V., \& Burns, E. E. (2013b). Incidence of and risk factors for perineal trauma: A prospective observational study. BMC Pregnancy and Childbirth, 
13(1), 4-9. https://doi.org/10.1186/14 71-2393-13-59

Varma, S. R., Sivaprakasam, T. O., Arumugam, I., Dilip, N., Raghuraman, M., Pavan, K. B., Paramesh, R. (2019). In vitro antiinflammatory and skin protective properties of Virgin coconut oil. Journal of Traditional and Complementary Medicine, 9(1), 514. https://doi.org/10.1016/j.jtcme.20 17.06.012

Wang, H., Jayasekara, R., \& Warland, J. (2015). The effect of " hands on " techniques on obstetric perineal laceration: A structured review of the literature. Women and Birth, 28 (3), 194-198. https://doi.org/10.1016 /j.wombi.2015.02.006

Zare, O., Pasha, H., \& Faramarzi, M. (2014). Effect of perineal massage on the incidence of episiotomy and perineal laceration. Health, 06(01), 10-14. https://doi.org/10.4236/heal th.2014.61003 